\title{
Kajian budaya organisasi dalam upaya peningkatan kinerja pegawai di Kalbis Institute
}

\author{
Windayanti*, Ignatius Ario Sumbogo, Nikolas Ivan \\ Waskita Adiyasa \\ Manajemen, Fakultas Bisnis Institut Teknologi dan Bisnis Kalbis
}

\begin{abstract}
This study aims to analyze the process of forming organizational culture at the Kalbis Institute, as well as providing advice and input on the application of work culture in improving employee performance at the Kalbis Institute. This study uses a qualitative approach with a qualitative descriptive design format through in-depth interviews and in-depth observation (participant observers) that will be conducted to research informants. Data validity and data credibility are tested using triangulation techniques. The conclusion of this study is the application of organizational culture and employee performance at Kalbis Institute is good enough
\end{abstract}

\begin{abstract}
Abstrak
Penelitian ini bertujuan untuk menganalisa proses terbentuknya budaya organisasi di Kalbis Institute, serta memberikan saran dan masukan tentang penerapan budaya kerja dalam meningkatkan kinerja pegawai di Kalbis Institute. Penelitian ini menggunakan pendekatan kualitatif dengan format desain deskriptif kualitatif melalui wawancara bertahap dan mendalam (in-depth interview) dan observasi partisipasi (participant observer) yang akan dilakukan kepada informan penelitian. Keabsahan data dan kredibilitas data diuji dengan menggunakan teknik triangulasi. Kesimpulan dari penelitian ini adalah penerapan budaya organisasi dan kinerja karyawan di Kalbis Institute sudah cukup baik..
\end{abstract}

*Email korespondensi: windayanti@kalbis.ac.id

Pedoman Sitasi: Windayanti, W., Sumbogo, I.A., \& Adiyasa, N.I.W. (2019). Kajian budaya dalam upaya peningkatan kinerja pegawai di Kalbis Institute. Jurnal Manajemen Strategi dan Aplikasi Bisnis, 2(2), 193 - 202
JMSAB

193

Paper type

Case Study

Keywords: organizational culture, employee performance.

Received: 5 Nov 2019

Revised: 27 Nov 2019

Accepted: 15 Dec 2019

Online: 20 Dec 2019

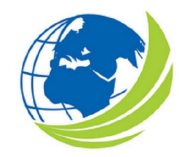

Jurnal Manajemen Strategi dan Aplikasi Bisnis, Vol 2, No.2, Agustus 2019, pp. $193-202$ eISSN 2655-237X 


\section{PENDAHULUAN}

Persaingan yang sangat ketat pada bidang pendidikan, menuntut Perguruan Tinggi Swasta (PTS) mempunyai keunggulan bersaing. PTS dalam mencapai keunggulan bersaing tersebut harus mengusahakan kinerja pegawai seoptimal mungkin. Di dunia bisnis hanya kinerja optimal yang dapat menjaga perusahaan untuk terus bertahan di dalam kompetisi global yang semakin tajam. Pada dasarnya kinerja pegawai mempengaruhi kinerja tim atau kelompok kerja dan pada akhirnya mempengaruhi kinerja perusahaan secara keseluruhan. Tidak hanya pengembangan teknologi informasi yang semakin canggih yang dibutuhkan oleh perguruan tinggi swasta, keterampilan manusia pun penting untuk dipadukan secara sistematis dengan teknologi dan informasi tersebut yang menjadi tulang punggung perkembangan perguruan tinggi swasta yang menjalankan kegiatan operasionalnya.

Kontribusi pegawai pada perguruan tinggi swasta akan menjadi penting, jika dilakukan dengan tindakan efektif dan berperilaku secara benar. Secanggih apapun teknologi dan informasi yang digunakan oleh suatu perguruan tinggi swasta apabila tidak didukung oleh sumber daya manusia yang kompeten dan berkinerja baik maka perusahaan tersebut tidak akan berjalan lancar. Kontribusi yang dilakukan tidak hanya jumlah usaha tetapi juga arah dari usaha itu. Sifat-sifat yang ada pada diri pegawai, upaya atau kemauan untuk bekerja, serta berbagai hal yang merupakan dukungan dari perusahaan sangat besar artinya bagi keberhasilan kinerja pegawai. Maka setiap pegawai perlu mengetahui dengan pasti apa yang menjadi tanggung jawabnya, kinerja seperti apa yang harus dicapainya serta dapat mengukur sendiri sesuai indikator keberhasilannya.

Pentingnya budaya organisasi dalam mempengaruhi kinerja pegawai telah banyak diteliti (misalnya Altındağ,\& Kösedağı, 2015; Naranjo-Valencia et al., 2016; Harwiki, 2016; Kawiana et al., 2018). Budaya organisasi dinyatakan memiliki korelasi yang signifikan dengan kinerja (Altındağ,\& Kösedağı, 2015; Kawiana et al., 2018). Dalam kontek yang berbeda, Naranjo-Valencia et al. (2016) menyimpulkan bahwa budaya dapat menumbuhkan inovasi, serta kinerja perusahaan, atau bisa juga menjadi hambatan bagi keduanya, tergantung pada nilai-nilai yang dipromosikan oleh budaya. Secara lebih spesifik, budaya adhokratis adalah inovasi dan prediktor kinerja terbaik. Namun, studi lain menyatakan bahwa budaya organisasi berdampak signifikan pada OCB, tetapi tidak signifikan terhadap kinerja karyawan (Harwiki, 2016). Masih adanya perbedaan hasil dalam menjelaskan efek budaya organisasi terhadap kinerja pegawai menunjukkan bahwa isu mengenai budaya organisasi ini tetap menarik untuk dipelajari lebih lanjut.

Berbeda dengan studi sebelumnya, penelitian ini bertujuan untuk mengekplorasi lebih dalam mengenai peran budaya organisasi dalam membentuk kinerja pegawai. Studi ini menggunakan pendekatan kualitatif untuk menjawab pertanyaan: (1) bagaimana proses budaya organisasi terbentuk di Kalbis Institute?; (2) bagaimana penerapan budaya kerja dalam meningkatkan kinerja pegawai di Kalbis Institute?. Manfaat studi adalah sebagai bagian dari evaluasi penerapan budaya organisasi sehingga dapat memberikan informasi tambahan untuk pengambilan keputusan di masa depan.

\section{KAJIAN PUSTAKA}

\section{Teori berbasis sumber daya}

Teori pandangan berbasis sumber daya (RBV) yang dikemukakan oleh Wernerfelt pada tahun 1984 menyatakan bahwa budaya organisasi mungkin merupakan sumber daya unik yang memungkinkan organisasi untuk membuat perbedaan antara mereka dan pesaing mereka (Barney, 1991). Ini menunjukkan bahwa, pengakuan budaya organisasi yang berkembang untuk peneliti manajemen sebagian besar dijelaskan dari sudut pandang RBV. Teori ini memandang budaya sebagai sumber daya yang halus, manajerial dan tidak berwujud yang berkontribusi terhadap keunggulan kompetitif (Flamholtz \& Randle, 2011; Owusu Ansah \& Louw, 2019). Para peneliti berpendapat bahwa, budaya 
organisasi adalah sumber daya taktis yang berkorelasi kuat dengan kinerja fiskal yang unggul (Barney, 1991) serta seluruh kinerja dalam organisasi. RBV telah menjadi kekuatan pendorong menuju pengembangan organisasi. Budaya organisasi dapat menolak upaya imitasi pesaing sambil berkontribusi lebih signifikan pada keunggulan yang berkelanjutan daripada sumber daya nyata (Owusu Ansah \& Louw, 2019).

\section{Budaya organisasi dan kinerja pegawai}

Budaya nasional dan budaya organisasi merupakan dua isu yang telah menjadi perdebatan yang tak henti-hentinya dalam literatur akademik tentang teori organisasi selama beberapa dekade (Atkinsonb \& Foroudic , 2017; Owusu Ansah \& Louw, 2019). Menurut Minkov dan Hofstede (2012) serta Klimas (2016) memahami budaya orang-orang dari lingkungan geografis yang berbeda memiliki kecenderungan untuk memberikan tanggapan terhadap tantangan bisnis internasional kontemporer. Schein (2004 dalam Hendryadi et al., 2019) mengungkapkan bahwa budaya organisasi adalah asumsi dasar yang ditemukan atau dikembangkan oleh sekelompok orang ketika mereka belajar untuk memecahkan masalah, beradaptasi dengan lingkungan eksternal, dan berintegrasi dengan baik untuk menyelesaikan masalah dalam organisasi. Perusahaan perlu mengembangkan budaya kerja yang kondusif bagi kemunculan dan bertumbuh kembangnya potensi dan kapabilitas anggotanya yang digunakan secara maksimal, kreatif dan bertanggung jawab agar menjadi kebanggaan organisasinya serta nilai-nilai yang dianut bersama membuat pegawai merasa nyaman bekerja, memiliki komitmen dan kesetiaan serta membuat pegawai berusaha lebih keras, meningkatkan kinerja dan kepuasaaan kerja serta mempertahankan keunggulan kompetitif.

Robbins dalam Sutrisno (2010:10) memberikan penjelasan bahwa budaya organisasi dalam suatu perusahaan mempunyai empat fungsi yaitu pertama "budaya organisasi berperan sebagai penentu batas-batas, artinya dengan budaya menciptakan perbedaan atau distingsi antara satu organisasi dengan organisasi lainnya. Kedua, budaya organisasi memuat rasa identitas anggota organisasi. Ketiga, budaya organisasi memfasilitasi lahirnya komitmen terhadap sesuatu yang lebih besar dari pada kepentingan individu. Keempat, budaya organisasi meningkatkan stabilitas sistem sosial." Pentingnya budaya organisasi bagi keberhasilan perusahaan disadari benar oleh Yayasan Pendidikan Kalbe Kalbis Institute. Kalbis Institute berupaya memperkuat budaya perusahaan dengan mengusung nilai Jujur, Adil, Konsisten, Bertanggung Jawab dan Peduli. Penerapan budaya organisasi juga bertujuan untuk meningkatkan daya saing jelang era Ekonomi Kreatif. Diharapkan melalui budaya organisasi ini akan berimbas pada kinerja pegawai Kalbis Institute.

Selain itu, sebagai manusia bersumber daya yang kredibel, pegawai memiliki berbagai jenis sumber daya yang bersifat nirwujud, seperti wawasan aspiratif, wawasan etikal, etos kerja, budaya kerja, semangat kebersamaan inklusif, semangat inovatif dan kompetensi. Kapabilitas sebuah perguruan tinggi tercermin dalam diri pegawai perusahaan tersebut, kapabilitas itu tidak akan mewujud apabila setiap pegawai tidak bersedia memunculkan dan memanfaatkannya bagi kepentingan perusahaan tersebut. Oleh karena itu, untuk mendukung kinerja pegawai agar dapat bekerja dengan lebih baik, tugas perusahaan adalah menggali potensi dalam diri setiap pegawai melalui budaya kerja yang menciptaan lingkungan yang kondusif, dimana setiap pegawai dapat tergugah semangatnya untuk memberi kontribusi yang terbaik bagi perusahaan.

Untuk memenuhi berbagai upaya tersebut, budaya organisasi yang menciptakan suatu budaya kerja yang kuat merupakan salah satu upaya yang dapat membantu kinerja pegawai lebih optimal karena budaya kerja yang kuat dapat menciptakan suatu tingkat motivasi yang luar biasa bagi pegawai untuk memberikan kemampuan terbaiknya dalam memanfaatkan kesempatan yang diberikan oleh organisasinya. Budaya organisasi dapat dijadikan sebagai fondasi. Sebagaimana layaknya sebuah bangunan, maka fondasi yang kuat dan sesuai dengan lingkungan tempatnya berdiri, akan dapat bertahan dalam waktu yang lama. Demikian pula dengan organisasi tersebut, 
dengan nilai-nilai budaya yang kuat dan diterima lingkungannya, maka organisasi tersebut memiliki kesempatan lebih besar untuk dapat terus berdiri dan berproduksi.

Dalam rangka mewujudkan budaya organisasi dalam membangun budaya kerja yang kuat yang cocok diterapkan diperlukan adanya dukungan dan partisipasi dari semua anggota yang ada dalam lingkup organisasi tersebut. Budaya organisasi merupakan nilai dan persepsi yang dianut bersama oleh setiap anggota organisasi. Maka pegawai membentuk persepsi mengenai kenyataan terhadap budaya organisasinya menjadi dasar pegawai itu berperilaku. Dari persepsi tersebut tercerminlah suatu tanggapan berupa dukungan pada karakrteristik organisasi yang selanjutnya membentuk budaya kerja serta mempengaruhi kinerja pegawai. Budaya organisasi merupakan konsep yang marak dibicarakan dalam dewasa ini sebagai bagian dari ilmu manajemen. Setiap organisasi harus memiliki kerangka dasar yang berlaku sebagai wadah untuk menampung komponen yang paling vital, yaitu manusia yang mempunyai nilai dan norma. Secara implisit berarti adanya pengakuan akan keberadaan nilai-nilai manusiawi dari dalam suatu perusahaan.

Maka fenomena pembentukan tim budaya organisasi, memberlakukan pedoman budaya perusahaan serta pembentukan agen perubahan dan pemimpin perubahan budaya organisasi di Kalbis Institute sangat menarik untuk dikaji. Langkah-langkah tersebut adalah salah satu bentuk upaya untuk meningkatkan kinerja pegawai Kalbis Institute agar lebih optimal. Banyak ahli menyebutkan bahwa budaya organisasi dapat menjadi basis adaptasi dan kunci keberhasilan organisasi sehingga banyak penelitian dilakukan untuk mengidentifikasi nilai-nilai atau normanorma perilaku yang dianut dan membentuk kekuatan budaya kerja yang selanjutnya bisa memberikan kontribusi besar bagi peningkatan kinerja pegawai dan berdampak positif bagi organisasi. Namun saat ini belum pernah dilakukan penelitian dan evaluasi budaya organisasi di Kalbis Institute berkaitan dengan kinerja pegawai.

\section{METODE}

\section{Pendekatan Yang Digunakan}

Penelitian ini menggunakan pendekatan kualitatif dengan format desain deskriptif kualitatif. Menurut Bungin (2007:68) format deskriptif kualitatif pada umumnya dilakukan pada penelitian dalam bentuk studi kasus. Deskriptif kualitatif studi kasus merupakan penelitian eksplorasi dan memainkan peranan sangat penting dalam menciptakan hipotesis atau pemahaman orang tentang berbagai variabel sosial. Format desain deskriptif kualitatif banyak memiliki kesamaan dengan desain deskriptif kuantitatif (Bungin, 2012:61).

\section{Teknik Pengumpulan Data}

Pengumpulan data kualitatif pada penelitian ini menggunakan metode pengamatan yang pada umumnya digunakan yaitu wawancara bertahap dan mendalam (in-depth interview), observasi partisipasi (participant observer) yang akan dilakukan kepada informan penelitian ini (Bungin:2007). Pengumpulan data pada penelitian kualitatif deskriptif ini dengan menyiapkan jadwal penelitian dan penganggaran, termasuk pengumpulan data di lapangan. Jadwal penelitian ini dibutuhkan untuk mengendalikan kelancaran penelitian.

Informan pada penelitian ini adalah informan yang menguasai informasi tentang Kalbis Institute. Cara memperoleh informan penelitian ini dengan menggunakan prosedur purposive. Bungin (2007:107) prosedur purposive adalah salah satu strategi menentukan informan yang paling umum di dalam penelitian kualitatif, yaitu menentukan kelompok peserta yang menjadi informan sesuai dengan kriteria terpilih yang relevan dengan masalah penelitian tertentu. Informan pada penelitian ini adalah key person yaitu Managing Director, Rektor dan Biro Jaminan Mutu Kalbis Institute. Ukuran besaran key person atau informan sudah ditetapkan sebelum pengumpulan data dengan menyesuaikan pada sumber daya dan waktu yang tersedia, serta tujuan penelitian. Kunci dasar penggunaan prosedur ini adalah penguasaan informasi dari informan dan secara logika bahwa 
tokoh-tokoh kunci di dalam penelitian ini menguasai informasi yang terjadi di dalam proses penelitian.

\section{Teknik Analisis Data}

Teknik analisa data pada penelitian ini adalah analisis data deskriptif-kualitatif yang pada dasarnya memiliki kesamaan dengan desain deskriptif-kuantitaif. Desain ini disebut dengan kuasi kualitatif atau desain kualitatif semu. Desain ini memnempatkan teori pada data yang diperoleh dalam penelitian (Bungin, 2007:150).

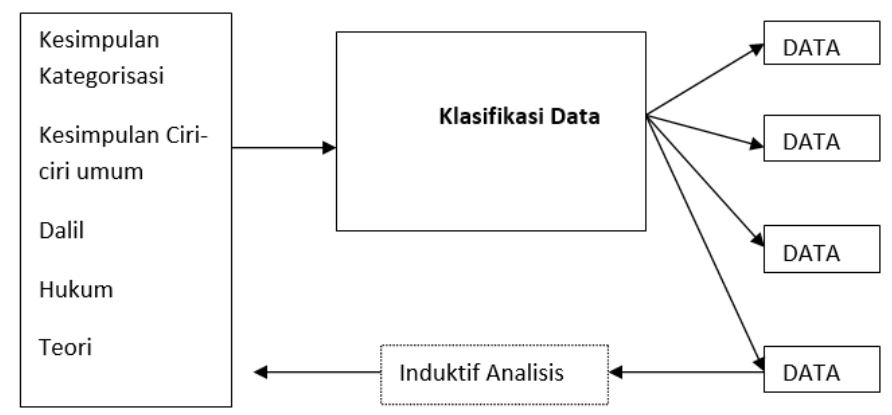

Gambar 1 Model Strategi Analisis Data Deskriptif-Kualitatif

Sumber: Bungin (2007)

Pada gambar 1 dijelaskan bahwa pada model strategi analisis data deskriptif-kualitatif bersifat kuasi kualitatif yaitu sifatnya tidak terlalu mengutamakan makna, sebaliknya penekanannya pada deskriptif menyebabkan format deskriptif kualitatif lebih banyak menganalisis permukaan data, hanya memperhatikan proses-proses kejadian suatu fenomena. Walaupun demikian, deskriptifkualitatif mengadopsi cara berpikir induktif untuk mengimbangi cara berpikir deduktif.

\section{Pengujian Keabsahan Data}

Dalam penelitian kualitatif, dilakukan melalui wawancara. Keabsahan data dan kredibilitas data diuji dengan menggunakan teknik triangulasi. Teknik triangulasi adalah menjaring data dengan berbagai metode dan cara dengan menyilangkan informasi yang diperoleh agar data yang didapatkan lebih lengkap dan sesuai dengan yang diharapkan. Triangulasi artinya menggunakan berbagai pendekatan dalam melakukan penelitian. Dalam penelitian kualitatif peneliti dapat menggunakan berbagai sumber data, teori, metode agar data dan informasi dapat diinterpretasikan secara konsisten. Setelah mendapatkan data yang jenuh yaitu keterangan yang didapatkan dari sumber-sumber data telah sama, maka data yang didapatkan lebih kredibel.

\section{HASIL DAN PEMBAHASAN}

\section{Sejarah Kalbis Instiitute}

Yayasan Pendiikan Kalbe (YPK) pada tanggal 1 Juni 1992 berdasarkan Surat Keputusan DIKTI nomor 221/ DIKTI/ Kep/ 1992 mendirikan Sekolah Tinggi Ilmu Ekonomi (STIE) Kalbe, kemudia pada tahun 2002 diubah namanya menjadi Sekolah Tinggi Ilmu Ekonomi (STIE) SUPRA. Pada tanggal 22 Mei 2006 berdasarkan Keputusan Menteri Pendidikan Nasional Republik Indonesia No.71/D/O/2006 YPK mendirikan Sekolah Tinggi Manajemen Informatika (STMK) SUPRA. Kemudia pada tanggal 2 November 2009 berdasarkan Keputusan Menteri Pendidikan Nasional REpublik Indonesia No. 187/D/O/2009 dilakukan penggabungan STIE SUPRA dengan STMIK SUPRA menjadi Institute Teknologi dan Bisnis Kalbe. Terhitung tanggal 18 Mei 2011, YPK menggandeng Yayasan Bina 
Nusantara sebagai mitra kerja untuk mengembangakn dan meningkatkan kinerja institut meliputi penyegaran dan perubahan strategi pengelolaaan lembaga. Seiring dengan itu YPK menetapkan perubahan nama Institut Teknologi dan Bisnis Kalbe menjadi Intitute Teknologi dan Bisnis Kalbis atau dengan nama singkatnya Kalbis Institute.

\section{Visi dan Misi Kalbis Institute}

Visi Kalbis Institute adalah:

"Menjadi Perguruan Tinggi pilihan di bidang sains, teknologi dan bisnis, menghasilkan luusan berkualitas dan siap terap, serta berorientasi pada inovasi, kewirausahaan dan globalisasi."

Visi tersebut akan menjadi landasan berpijak bagi perencanaan tahapan pengembangan hingga sampai tahun 2020. Visi ini kemudian diturunkan sesuai dengan good governance yang dianut oleh Kalbis Institute menjadi misi, tujuan, strategi dan rencana jangka pendek yang key performance indicatorn-nya dituangkan dalam Balance Scorecard Institute Teknologi dan Bisnis Kalbis.

Dalam upaya mencapai visinya, Kalbis Institute telah menetapkan misi sebagai berikut:

a. Menyelenggarakan kegiatan pendidikan tinggi di bidang sains, teknologi, dan bisnis yang ditunjang oleh penerapan teknologi informasi dan sistem manajemen mutu.

b. Menyediakan saranan dan lingkungan yang kondusif bagi pelaksanaan kefiatan pembelajaran yang efektif dan efisien sehingga dapat menghasilkan lulusan terampil, kreatif dan inovatif.

c. Mengembangkan karakter yang baik, jiwa kepemimpinan dan kewirausahaan, serta kemampuan softskill peserta didik.

d. Menjaga keterkaitan/relevansi seluruh kegiatan pendidikan dengan kebutuhan pembangunan sosial-ekonomi dan industri secara globa.

e. Memberi kontribusi dalam meningkatkan kualitas hidup masyarakat melaui kegiatan penelitian terapan dan pengabdian kepada masyarakat.

\section{Tujuan}

Kalbis Institute menetapkan tujuan sebagai berikut:

a. Meningkatkan kompetensi lulusan agar siap berkompetisi dan bekerja atau berwirausaha di dunia global.

b. Meningkatkan kapasitas akademis yang kondusif bagi proses belajar mengajar yang efektif.

c. Mneingkatkan kapasitas penelitian dan hasil penelitian, publikasi dab pengabdian kepada masyarakat.

Meningkatkan paparan global melalui kerjasama dengan industry dan perguruan tinggi baik dalam maupun luar negeri.

\section{Nilai-Nilai}

Nilai-nilai yang dianut Kalbis Institute merupakan nilai-nilai yang dipegang teguh oleh seluruh dosen, mahasiswa, staf dan karyawan dalam kegiatan sehari-hari sebagai berikut:

1. Jujur. Selalu bersikap atau memberikan suatu informasi sesuai dengan kenyataan dan kebenaran.

2. Adil. Selalu bersikap obyektif berdasarkan fakta dan kebenaran serta sesuai peraturan yang berlaku di dalam mengambil keputusan.

3. Konsisten. Senantiasa tidak berubah-ubah dan taat asas dalam bersikap atau bertindak.

4. Bertanggung jawab. Senantiasa siap menerima dan melaksanakan kwajiban dan tugas, serta siap menanggung hasil dan akibatnya.

5. Peduli. Memiliki sikap memperhatikan dan mengindahkan keadaan di sekeliling terutama bagi yang membutuhkan pertolongan.

\section{Kebijakan Mutu}

Sistem penjaminan mutu yang dikembangkan mengacu kepada Standar Nasional Pendidikan yang pada penerapannya disusun menggunakan kerangka penjaminan mutu ISO 9001:2008. Kalbis Institute telah menetapkan Kebijakan Mutunya sebagai berikut: 
"Kami bertekad memberikan layanan pendidikan unggul yang mendukung terciptanya inovasi, semangat kewirausahaan, dan peningkatan daya saing dalam era globalisasi."

\section{Budaya Organisasi Dalam Upaya Peningkatan Kinerja Pegawai Kalbis Institute}

Dari hasil temuan peneliti di lapangan, terlihat pola munculnya budaya organisasi yang tumbuh di Kalbis Institute yaitu pada slogan "Saya bisa, kamu bisa, kita semua bisa. Kalbiser!" yang selalu diucapkan dan pada symbol tangan membentuk " $\mathrm{K}$ " pada saat acara atau kegiatan Kalbis dilaksanakan. Budaya organisasi ini diciptakan oleh manajemen puncak Kalbis Institute lalu diimplementasikan menjadi visi misi atau strategi bisnis.

Budaya Organisasi adalah sistem nilai bersama dalam suatu organisasi yang menentukan tingkatan bagaimana para karyawan melakukan kegiatan untuk mencapai tujuan organisasi (Robbins dalam Sutrisno, 2011:24). Kalbis Institute memiliki sistem nilai bersama yang mampu dijalankan oleh karyawannya dengan semangat tinggi salah satunya adalah pelaksanaan acara rekreasi karyawan. Sedangkan pengertian budaya organisasi menurut Susanto dalam Sutrisno (2011:24) adalah nilai-nilai yang menjadi pegangan Sumber Daya Manusia (SDM) dalam menjalankan kewajiban dan merupakan landasan berperilaku dalam organisasi. Serta menjadi pedoman untuk menghadapi permasalahan eksternal dan usaha penyesuaian integrasi ke dalam organisasi sehingga mereka mengetahui bagaimana mereka harus bertindak atau berperilaku. Namun untuk mencapai budaya organisasi sebagai pedoman ini diperlukan karakter utama dari organisasi sebagai perangkat mengarahkan perilaku pegawai untuk melakukan pekerjaan yang dijalankannya.

Organisasi dengan budaya tertentu memberikan daya tarik bagi individu dengan karakteristik tertentu untuk bergabung. Budaya organisasi bersifat nonformal atau tidak tertulis namun mempunyai peranan penting sebagai cara berpikir, menerima keadaan dan merasakan sesuatu dalam perusahaan tersebut. Hal ini diakui oleh salah satu narasumber dari Kalbis Institute yang menjelaskan bahwa dalam membangun budaya organisasi khususnya pada proses pembentukan budaya organisasi.

Budaya organisasi yang diterapkan oleh pimpinan Kalbis Institute dapat dilihat dari ciri khas penampilan pegawai dalam penggunaan seragam yang dipakai oleh pegawai Kalbis Institute setiap hari Selasa yang menjadikan satu identitas kebanggan pegawai pada saat menggunakan seragam tersebut. Budaya organisasi pada Kalbis Institute baik maka norma yang terbentuk juga baik, dari pengamatan dan hasil wawancara terbentuk norma yang harus dipatuhi oleh para anggota organisasi. Dalam membangun budaya organisasi, Kalbis Intitute juga rutin melakukan kegiatan halal bihalal di setiap tahunnya dengan melibatkan seluruh pegawai. Kondisi budaya di tempat kerja Kalbis Institute dipaparkan dengan hubungan vertikal yang terdapat di tempat kerja. Dari pengamatan dan hasil wawancara bahwa budaya yang tumbuh pada Kalbis Institute termasuk baik sehingga terbentuklah nilai-nilai budaya sebagai berikut:

1. Jujur. Selalu bersikap atau memberikan suatu informasi sesuai dengan kenyataan dan kebeneran.

2. Adil. Selalu bersikap obyektif berdasarkan fakta dan kebenaran serta sesuai peraturan yang berlaku di dalam mengambil keputusan.

3. Konsisten. Senantiasa tidak berubah-ubah dan taat asas dalam bersikap atau bertindak.

4. Bertanggung jawab. Senantiasa siap menerima dan melaksanakan kwajiban dan tugas, serta siap menanggung hasil dan akibatnya.

5. Peduli. Memiliki sikap memperhatikan dan mengindahkan keadaan di sekeliling terutama bagi yang membutuhkan pertolongan.

Dengan adanya nilai budaya organisasi yang berperan sebagai pembinaan perilaku, maka para pegawai dapat membedakan mana yang harus dikerjakan dan mana yang tidak perlu dikerjakan. Nilai-nilai budaya organisasi tersebut diimplementasikan melalui pembinaan, bimbingan, dan keterbukaan dalam berkomunikasi dengan mengambil keputusan, membudayakan saling membantu dalam bekerja, dan membudayakan taat pada peraturan yang harus diterapkan pada setiap pegawai 
agar dapat memberikan hasil kerja yang tinggi. Hal tersebut ditanamkan agar lebih konsisten dengan visi dan misi Kalbis Institute.

Dari hasil pengamatan dan wawancara, budaya kerja juga terimplementasi dengan melekatnya tingkat keyakinan anggota organisasi, melalui hubungan kerjasama yang baik, melaksanakan tujuan organisasi secara efektif dan efisien sehingga dapat meningkatkan keyakinan diri pegawai dalam mencapai target dan memiliki keyakinan bahwa setiap orang dalam organisasi tersebut memiliki kemampuan untuk ikut serta dalam memajukan organisasi sesuai dengan visi misi yang tertera di Kalbis Institute. Hasil pengamatan dan wawancara budaya organisasi dalam upaya meningkatkan kinerja pegawai pada Kalbis Institute juga termasuk baik. Hal ini ditegaskan oleh responden R1.

"Karyawan menyesuaikan diri dan beradaptasi dalam menjalankan kewajibannya sebagai anggota organisasi. Hal ini terlihat dari sebagian besar cukup baik dengan lingkungan pekerjaan."

Kinerja seperti yang disampaikan oleh Rivai (2011:14), kinerja adalah hasil atau tingkat keberhasilan seseorang secara keseluruhan selama periode tertentu di dalam melaksanakan tugas, dibandingkan dengan berbagai kemungkinan, seperti standar hasil kerja, target dan sasaran atau kriteria yang telah ditentukan terlebih dahulu dan telah disepakati bersama. Kinerja pegawai Kalbis Institute termasuk baik, seperti yang dijelaskan oleh responden R1.

"Setiap pegawai yang dapat memberikan prestasi kerja yang sesuai dengan standar hasil kerja target dan sasaran seperti Kalbis Institute yang mengadopsi key performance indikator akan diberikan reward sepesifik sesuai dengan hasil kerjanya salahsatunya adalah promosi jabatan."

Hasil kerja secara kualitas dan kuantitas yang dicapai oleh pegawai setelah melakukan rangkaian proses pekerjaan yang dibebankan sesuai dengan standar dan kriteria yang telah ditetapkan dalam mencapai tujuan strategis perusahaan.

Responden R2 memberikan penjelasan bahwa Kalbis Institute dalam upaya meningkatkan dan mengharmonisasikan pegawai yang sangat bervariasi harus disesuaikan dengan potensi pegawai.

"Setiap manusia pasti ada manfaatnya, tinggal bagaimana cara organisasi memaksimalkan potensinya dan potensi pegawai diapresiasi tepat oleh organisasi."

Kalbis Institute dalam upaya meningkatkan kinerja pegawainya dituangkan dalam kebijakan mutu atau sistem penjaminan mutu yang dikembangkan mengacu kepada Standar Nasional Pendidikan yang pada penerapannya disusun menggunakan kerangka penjaminan mutu ISO 9001:2008. Kalbis Institute telah menetapkan Kebijakan Mutunya sebagai berikut:

"Kami bertekad memberikan layanan pendidikan unggul yang mendukung terciptanya inovasi, semangat kewirausahaan, dan peningkatan daya saing dalam era globalisasi."

Budaya organisasi dalam upaya meningkatkan kinerja karyawan juga baik tercermin berdasarkan dari sasaran mutu Kalbis Institute melengkapi dan memantau keberhasilan impelemnatsi kebijakan mutunya menetapkan beberapa sasaran mutu.

\section{KESIMPULAN}

\section{Kesimpulan}

Berdasarkan hasil dan wawancara yang peneliti lakukan terlihat bahwa penerapan budaya organisasi sudah cukup baik, dengan adanya penyesuaian dan adaptasi karyawan dan adanya sosialisasi budaya organiasi melalui nilai-nilai yang tekandung dalam visi misi, nilai-nilai dan tujuan Kalbis Institute berdampak memberikan pengetahuan tentang budaya organisasi. Kinerja karyawan juga sudah baik dengan mengacu pada penjaminan mutu Kalbis Institute memberikan pemahaman 
kepada karyawan bahwa penerapan nilai-nilai budaya ditanamkan sejak seseorang mulai bergabung menjadi anggota organisasi dan menemukan peran budaya organisasi sebagai pedoman bagi anggota organisasi

\section{Implikasi Praktis / Teoritis}

Hasil studi ini memperlihatkan bahwa secara umum pegawai memiliki pemahaman yang baik mengenai budaya organisasi sehingga menjadi kekuatan utama organisasi untuk terus mendorong penguatan nilai-nilai budaya melalui berbagai kegiatan formal maupun tidak formal. Kegiatan formal seperti gathering dapat mempererat hubungan sosial diantara pegawai, maupun melalui kegiatan non-formal seperti aktivitas sehari-hari pimpinan yang terus menerus mengingatkan nilai-nilai budaya yang dianut oleh organisasi.

\section{Keterbasan dan Saran}

Penelitian ini menggunakan pendekatan studi kasus pada satu organisasi sehingga memiliki keterbatasan dari sisi generalisasi. Riset berikutnya dapat mengkonfirmasi ulang dengan menggunakan pendekatan ekplanasi yaitu menjelaskan hubungan budaya dan kinerja pegawai secara empiris dengan menggunakan pendekatan kuantitatif.

\section{REFERENSI}

Altındağ, E., \& Kösedağı, Y. (2015). The relationship between emotional intelligence of managers, innovative corporate culture and employee performance. Procedia-Social and Behavioral Sciences, 210, 270-282.

Barney, J. (1991). Firm resources and sustained competitive advantage. Journal of Management, 17, 99-120

Bungin, B. (2007). Penelitian kualitatif: komunikasi, ekonomi, kebijakan publik, dan ilmu sosial lainnya. Kencana.

Harwiki, W. (2016). The impact of servant leadership on organization culture, organizational commitment, organizational citizenship behaviour (OCB) and employee performance in women cooperatives. Procedia-Social and Behavioral Sciences, 219, 283-290.

Hendryadi, Suratna, Suryani, \& Purwanto, B. (2019). Bureaucratic culture, empowering leadership, affective commitment, and knowledge sharing behavior in Indonesian government public services. Cogent Business \& Management, 6(1), 1680099.

Kawiana, I. G. P., Dewi, L. K. C., Martini, L. K. B., \& Suardana, I. B. R. (2018). The influence of organizational culture, employee satisfaction, personality, and organizational commitment towards employee performance. International research journal of management, IT and social sciences, 5(3), 35-45.

Klimas, P. (2016). Organizational culture and coopetition: An exploratory study of the features, models and role in the Polish Aviation Industry. Industrial Marketing Management, 53, 91-102.

Minkov, M., \& Hofstede, G. (2012). Is national culture a meaningful concept? Cultural values delineate homogeneous national clusters of in-country regions. Cross-Cultural Research, 46, 133-159.

Naranjo-Valencia, J. C., Jiménez-Jiménez, D., \& Sanz-Valle, R. (2016). Studying the links between organizational culture, innovation, and performance in Spanish companies. Revista Latinoamericana de Psicología, 48(1), 30-41.

Nazariana, A., Atkinsonb, P., \& Foroudic, P. (2017). Influence of national culture and balanced organizational culture on the hotel industry's performance. International Journal of Hospitality Management, 63(2017), 22-32.

Owusu Ansah, M., \& Louw, L. (2019). The influence of national culture on organizational culture of multinational companies. Cogent Social Sciences, (just-accepted), 1623648.

Robbins, S. P., \& Judge, T. A. (2013). Organizational behavior. Pearson education limited.

Sutrisno, E. (2010). Budaya Organisasi. Jakarta: Kencana Prenada Media Group 


\section{PROFIL PENULIS}

Windayanti adalah Dosen Program Studi Manajemen Fakultas Bisnis Kalbis Institute dengan pengalaman mengajar berbagai bidang manajemen pada tingkat sarjana dan pascasarjana.Berkarir sebagai praktisi sejak tahun 1997 dan berpengalaman di bidang Human Resources Management, Auditor, Education Consulting dan Management Consulting, aktif sebagai pembicara pada seminar, workshop dan pelatihan Human Resources. Koresponden penulis dapat dihubungi di: windayanti@kalbis.ac.id 